\title{
Bilinçli Tüketim Kavramının Boyutları: Bilinçli Tüketim Davranışının Yeniden Tanımlanması'
}

Esna Betül BUĞDAY, Department of Family and Consumer Sciences, Faculty of Economics and Administrative Sciences, Hacettepe University, Turkey; e-mail: betul.surgit@hacettepe.edu.tr

Müberra BABAOĞUL, Department of Family and Consumer Sciences, Faculty of Economics and Administrative Sciences, Hacettepe University, Turkey; e-mail: muberra@hacettepe.edu.tr

\section{Dimensions of Conscious Consumption Concept: Redefinition of Conscious Consumption Behaviour ${ }^{2}$}

\begin{abstract}
It is not possible for the consumer behaviors of the individuals not to affect every aspect of life. In consumer society in which the concept of consuming for the sake of consumption is adapted and individualist ideology comes to the forefront, the fact that the individuals consume irresponsibly and without thinking makes people face many risks and problems in environmental, social and ethical aspects. There is a need for trained consumers who are conscious and the generation of a new concept of consumption based on awareness, responsibility and ethics in order to be able to both raise the life standards of individuals as consumers and to be able to maintain this by meeting their needs and also for the development of society. Within the scope of the study, a multidimensional and comprehensive scale of conscious consumer has been developed in a way that will contain the dimensions of "socially responsible consumption", "ethical consumption", "simple consumption", and "eco-friendly consumption" and supposed to be a guide for the society.
\end{abstract}

Keywords : Conscious Consumption, Conscious Consumer, Socially Responsible, Ethical, Simple Consumption.

JEL Classification Codes : D18, E21, M14.

\section{Öz}

Bireylerin tüketim davranışlarının hayatın her yönünü etkilememesi mümkün değildir. Tüketim için tüketmek anlayışının benimsendiği ve bireyci ideolojinin ön plana çıktığı tüketim toplumunda, bireylerin sorumsuzca ve düşünmeden tüketmesi insanları çevresel, toplumsal ve etik açıdan birçok risk ile karşı karşıya getirmektedir. Hem tüketici olarak bireylerin, ihtiyaçlarını karşılayarak yaşam düzeylerini yükseltebilmek hem de toplumun kalkınması için bilinçli ve sorumlu eğitilmiş tüketicilere ve bilinç, sorumluluk ve etik temelli yeni bir tüketim anlayışının oluşmasına

I Bu çalışma “Bilinçli Tüketici Ölçeği Geliştirme Çalışması” başlıklı doktora tezinden üretilmiştir.

2 This article is produced from dissertation titled as "A Study on the Development of Conscious Consumer Scale". 
gerek vardır. Bu çalışma kapsamında sosyal sorumlu, çevre bilinçli, etik, sade tüketim ve rasyonel tüketim olmak üzere beş boyuttan oluşan ve toplum refahı için bir rehber olması düşünülen çok kapsamlı bir bilinçli tüketim davranışının sınırları çizilmeye çalışılmıştır.

Anahtar Sözcükler $\quad$ : Bilinçli Tüketim, Bilinçli Tüketici, Sosyal Sorumlu, Etik, Sade Tüketim.

\section{Tüketim ve Bilinç İlişskisi}

Tarih boyunca toplumlar, içerisinde yaşanan değişimler ve dinamiklerine göre tarım toplumu, sanayi toplumu, modern toplum, bilgi toplumu, post modern toplum, risk toplumu ve tüketim toplumu gibi isimler almışlardır. Tüm bu adlandırmalar, içinde bulunulan evrenin dinamiklerini ve bu evrede toplumun nasıl bir yapılanma içinde olduğunu açılamaya çalışmaktadır. Bu toplumların içerisinde yaşayan bireyler de farklı değerler, tutumlar ve davranışlarla şekillenmektedirler. Örneğin sanayi öncesi geleneksel toplum yapısında bireyler doğal yollardan ihtiyacını giderme ve var olanla yetinme değerlerine sahipken, modern sanayi toplumunda bireyler için emek, çalışma gibi değerler ön plana çıkmakta, sanayi sonrası evreyi tanımlayan tüketim toplumunda ise tüm değerlerin yerini aşırı tüketim almaktadır (Şentürk, 2008: 223).

Geleneksel toplum yapısından çok farklı bir toplumsal pratiği ifade eden modern toplum yapısı, Avrupa'da aydınlanma çağıyla başlayan ve sonraları bütün dünyayı etkisi altına alan Batı'ya özgü ekonomik ve sosyo-kültürel yaşam biçiminin adıdır (Giddens, 1998: 9). Modern toplumda feodalizmin dayandığ tarım ekonomisi ve din odaklı düşünme geride bırakılarak, sanayide makineleşmeye dayanan kapitalist ekonomiye ve bilimsel ve akıl odaklı düşünce sistemine geçilmiştir (Odabaş1; 2004: 14). 19. yüzyılın sonuna kadar devam eden modern sanayi toplumunda bireylere sürekli ve durmaksızın çalışma ve üretme öğütlenmektedir. Bu toplumun sembol kavramı üretimdir (Ekin, 2010: 16). Bu toplum yapısı, akılcılık ve ilerleme inancı üzerine kuruludur. Sanayi toplumunun çalışma etiğinin temelini mümkün olduğunca çok çalışma oluşturmaktadır (Bauman, 1999: 14-16). Bu dönemde sanayileşmeyi şekillendiren önemli bir unsur olarak "püriten etik" öne çıkmaktadır. Püriten etik, sanayileşme döneminde kapitalizme hayat veren bir görüştür. Artan üretim, azalan tüketim şeklinde kendini gösterir. Temelinde, çalışmanın ve üretmenin bireye hem bu dünyada hem de diğer dünyada mutluluk sağlayacağı görüşü vardır. Tatmine, zevk ve eğlenceye dayalı olan, hedonik ve gösteriş tüketimine püriten etikte yer yoktur (Şentürk, 2008: 224). Püriten etik, çok üretip az tüketme, elindekini rasyonel kullanma üzerine kurulu bir etik anlayışıdır.

Çalışma, emek ve üretime dayalı modern çağı izleyen çağ farklı teorisyenler tarafından farklı kavramlarla adlandırılmıştır. Giddens bu yeni döneme "geç modern", Beck "düşünümsel modern", Balandier "modernötesi”, John Tomlinson ise " postmodern" adını vermektedir (Bauman, 1999: 33). Bu yeni toplumsal yapının en önemli özelliği harcama, savurganlık ve tüketimin yükselişe geçmesidir (Şentürk, 2008). Touraine (2000), bu sürecin tüketim toplumuna giriş ve modernlikten çıkış anlamına geldiğini belirtmektedir. $\mathrm{Bu}$ dönemde tüketimin anlamında ciddi değişmeler yaşanması ve tüketim kültürünün yoğunlaşması nedeniyle post modern toplum tüketim toplumu olarak da adlandırılmaktadır. 
Günümüzde tüm toplumların temel özelliği haline gelen tüketim olgusu, 20. yy’ın son çeyreğinden itibaren ekonomik bir olgu olmanın yanı sıra kültürel, psikolojik ve sosyal bir olgu olarak da belirginleşmeye başlamıştır. Tüketim artık sadece temel ihtiyaçların karşılanmasına yönelik bir faaliyet olmaktan çıkmış ve geleneksel işlevinden uzaklaşarak, bireylerin istek ve arzularının tatmininin sağlanması, kimlik oluşturma, ve statü göstergesi olma gibi yeni anlamlar kazanmıştır. Tüketim toplumsal bir olgu olarak, insanların toplumda kabul görme ve itibar kazanma ihtiyacını tatmin ettiği bir faaliyet biçimindedir. Kültürel olarak ise bireylerin duygularını ortaya koyan ve çevresiyle iletişim kurmasını sağlayan bir araçtır (Kahvecioğlu, 2004: 42).

20. yüzyıl sonrası kapitalizminin bireylere yüklediği görev harcama isteğini üstün tutarak sürekli tüketimi artırmasıdır (Fromm, 2002: 49-50). Tüketim toplumunda bireyler tüketici olarak yetenekleriyle önem kazanmakta, ekonomik sistemin sürdürülebilmesi için bireylere tüketici olarak ihtiyaç duyulmaktadır (Bauman, 2006). 19. Yüzyılda bireyleri çalışma üzerinden sömüren kapitalist sistem, bu sömürüyü 20. yüzyılda tüketim üzerinden gerçekleştirmektedir. Baudrillard, sistem tarafından bireylere verilen "tüketme" görevini "toplumsal iş" olarak nitelendirmektedir. Sanayi toplumunda yaşayan bireyler için toplumsal iş çalışmak ve durmadan üretmek iken, sanayi sonrası toplum bireyleri için bu iş "tüketmek ve daha çok tüketmek" tir. "Toplumsal iş" ini yerine getirmeyerek, ihtiyaçları doğrultusunda tüketim faaliyetinde bulunan bireyler, toplum tarafindan "ikinci sınıf" ve "öteki” olarak görülmekte ve dişlanmaktadır. Çünkü ekonomik sistem, sürekli tüketen ve sürekli isteyen bireylere ihtiyaç duymaktadır (İnsel, 1997: 21).

Tüketim toplumunda bireyler tüketimin ana amacını sorgulamaktan uzaklaşmakta, varoluşsal kaygılarından kurtulmakta ve tüketimi bir araç olarak kullanmaktadırlar. Bu yönüyle tüketim, duygusal ve düşünsel varlığın korunmasını sağlayan bir olgu haline gelmektedir. Günümüzde tüketim “eksiklik” üzerine kurulmuştur. Tüketim kültürü bireyleri sürekli satın almaya yönlendiren, "yanlış ve sahte ihtiyaçlar" üretmektedir. Bireyler tüketime eleştirel bakmayı bir yana bırakarak, tüketimi yaratıcılığın ve ekonominin dinamosu olarak görmektedirler ve ekonomik sisteme tüketerek dâhil olmaktadırlar (Bauman, 2006: 94).

Vazgeçilmez, yaşamsal bir faaliyet olan tüketimin, dünyayı ve yaşamı yok eden bir faaliyete dönüştüğü bu toplum yapısı ve kültürü pek çok teorisyen tarafından sert bir şekilde eleştirilmiştir. Frankfurt Okulu tüketim kültürüne yönelik eleştirilerini Max Horkheimer ve Thedor W. Adorno'nun “Aydınlanmanın Diyalektiği” eserinde "kültür endüstrisine" dayalı olarak ifade etmektedirler. $\mathrm{Bu}$ düşünürlere göre, kültür endüstrisi tüketicileri bir kalıba sığdırmaya çalışarak kendine uydurmakta ve çok ince ve etkin yöntemlerle onları baskı altında tutmaktadır. Tüketim kültüründe herkesin ihtiyaç ve isteklerine uygun bir ürün mutlaka vardır. "Kimse kaçamasın diye" her tüketici grubu için bir ürün üretilmiştir. Tüketiciler de kendilerine uygun görülerek üretilen bu ürünleri sorgulamadan kabullenmekte ve tüketmektedirler (Şan \& Hira, 2007).

Adorno ve Horkheimer'dan sonra tüketim kültürünü eleştiren bir diğer teorisyen de Herbert Marcuse'dur. Marcuse (1986), tüketim kültürünün bireysellik temelli olduğunu 
ifade ederek bu kültüre karşı kötümser bir bakış açısı sergileyen ilk düşünürlerdendir. Bu görüşlerini Tek Boyutlu İnsan adlı eserinde belirtmiştir. Marcuse, tüketim kültürü ile her şeyin tümden farklılaştığına dikkat çekmekte, daha geniş maddi bolluk ve tüketimin, her şeye kolay bir şekilde ulaşmanın, düşüncelerin manipülasyonunun kolaylaşmasına, manevi ve entelektüel zenginliklerin azalmasına ve varlığın değer yitirmesine yol açtığını belirtmektedir. Bunun yanı sıra Marcuse, bireylerin tüketim davranışlarının üretim sistemleri aracılığıyla şekillendiğini ve bu sistemde bireylerin köleleştirildiğini ifade etmekte, ancak bu durumun değişmez olmadığını, bireylerin entelektüeller öncülüğünde bilinçlenmesi gerektiğini vurgulamaktadır.

Tüketim toplumu ile ilgili en çok sorgulanması gereken noktalardan biri de bu kadar bolluğun yaşandığı bir çağda tatminsizliğinin artışıdır. Zira içinde yaşadığımız çağ, niceliksel fazlalık ancak niteliksel yoksulluk çağı olarak değerlendirilebilir (Coşgun, 2012: 842). Sonuç olarak günümüz toplumu, ekonomik, sosyal ve kültürel tüm ilişkilerin tüketim kavramı etrafında kurulduğu, tüketimin niceliksel olarak ciddi boyutlara ulaştığı ve tüm sistemin tüketime bağımlı olduğu bir toplum haline gelmiştir.

Bireylerin tüketim davranışlarının hayatın her yönünü etkilememesi mümkün değildir. Tüketim için tüketmek anlayışının benimsendiği ve bireyci ideolojinin ön plana çıktığı tüketim toplumunda, bireylerin sorumsuzca ve düşünmeden tüketmesi insanları çevresel, toplumsal ve etik açıdan birçok risk ile karşı karşıya getirmektedir.

Öncelikli olarak, tüketim toplumundaki sınırsız tüketim anlayışı, insanın doğa ile uyumlu yaşaması yerine, kaynakların kötü kullanımına ve israfa yol açmaktadır (Tolan, 1991: 297-298). İsrafa dayalı tüketim anlayışı, sınırlı kaynakların giderek yok olmasına yol açarak çevreyi tahrip etmektedir. Daha fazla enerji tüketimi için yapılan nükleer santraller, ekolojik dengenin bozulması, toprak kaybı, yok olan doğal kaynaklar, ormanların bilinçli olarak yok edilmesi, çölleşme, biyolojik çeşitliliğin azalması, temiz su kaynaklarının kirletilmesi, hava kirliliği, küresel ısınma ve küresel iklim değişikliği, ozon tabakasının delinmesi ve radyoaktif atıklar gibi ciddi çevre problemleri, "istediğin kadar tüket, hep tüket” anlayışının sonucudur (Kahvecioğlu, 2004). Tüm bu çevre sorunlarının çözümlenebilmesi için sürdürülebilir tüketime dayalı yeni bir yaşam tarzını benimsemiş ve çevre konusunda bilinçlenmiş tüketicilere ihtiyaç vardır.

Sorgulamadan aşırı tüketmenin diğer bir boyutu da bu tüketimin sebep olduğu toplumsal sorunlardır. Maddi ve manevi tüm metaların bilinçsizce tüketildiği tüketim kültürü, toplumu ve sosyal çevreyi yaşanmaz hale getirmektedir. Öncelikle kitlesel tüketim kitlesel üretimi gerektirir. Daha fazla tüketimin gerçekleştirilebilmesi için özellikle az gelişmiş ve gelişmemiş ülkelerde, bu üretim faaliyetlerinde çocuk işçilerin çalıştırılması, işçilerin kötü çalışma koşullarında ve düşük ücretlerle çalışmak zorunda bırakılması, işçi sağlığı ve iş güvenliğinin hiçe sayılması ve böylece emeğin sömürülmesi bu sorunların başında gelmektedir (Rey \& Ritzer, 2012: 449). Bunun yanı sıra, dünyanın belli ülkelerinde israf ekonomisi varlığını sürdürürken, az gelişmiş ülkelerde insanlar "küresel açlık" ile mücadele etmektedir (Ünay, 2010: 73). Diğer bir deyişle, dünyada metalar eşit olarak paylaşılmamaktadır. Etnik azınlıklar, kadınlar, işsizler, çocuklar, gençler, yaşlılar ve üçüncü 
dünya ülkelerinde yaşayan nüfus kaynaklara erişim konusunda eşit firsatlara sahip değillerdir. Kaynak dağılımındaki bu eşitsizlik, fakirlik, cahillik ile birleşerek bireyler arasında çatışmalara sebep olabilmektedir. Bunun temel sebebi logoların görsel algılanmasına dayalı olarak evrensel bir tüketim dili yakalayan tüketim kültürüdür (Weber, 1999: 40). Sosyal adalet söyleminin tüketimle kesiştiği nokta da tam olarak yukarıda bahsedilen problemlerin çözümündedir. $\mathrm{Bu}$ problemlerin çözümünde anahtar rolü oynayacak olan kitle de tüketim faaliyetinin topluma etkilerinin bilincinde olan, gerektiğinde işletmelerin faaliyetlerine yön verebilmek için satın almama ya da boykot etme hakkını kullanabilen ve gücünün farkında olan, sosyal olarak bilinçli tüketicilerdir.

Ayrica en yoksul kesimde yaşayan bireylerin bile teknolojinin gelişimi yoluyla zengin kesimin sürdürdüğü yaşam tarzını görmesi ve özenmesi, toplumda zenginlik algısının öne çıkması, lüks, marka gibi kavramların tüm bireylerin önemsediği yaşamsal değerler arasında yer alması, yaşama ilişkin amaçların metalaşması, başarının para ve edinilen metalar üzerinden ölçülmesi, dayanışma ve paylaşma duygusunun yerini bireyselliğin alması bireyleri mutlak bir mutsuzluğa ve tatminsizliğe götürmekte ve daha sade ve topluma daha duyarlı bir tüketim modelini gerekli kılmaktadır.

Bunun yanı sıra giderek karmaşıklaşan pazar yapısı ve gelişen pazarlama faaliyetleri sonucunda tüketiciler kolaylıkla manipüle edilmekte, kitle iletişim araçlarının da etkisiyle fiyat, kalite, moda gibi kavramlar tüketicilerin satın alma davranışlarında sorumlu ve etik davranışlarının önüne geçebilmektedir. Bunun sonucunda tüketicilerde mağaza hırsızlığg, kaçak mal ya da korsan ürün kullanma gibi etik olmayan davranışlar görülebilmektedir. Tüketiciler kendilerine cazip gelen bir malı satın alabilmek için etik ticaret ilkelerine uymayan ve sosyal sorumluluk taşımayan işletmelerden alışveriş yapabilmektedirler. Bu da pazarın güvenirliğini bozmaktadır. Erdemli tüketiciler olmadan erdemli işletmelerin olması mümkün değildir.

Tüm bu nedenlerden dolayı hem tüketici olarak bireylerin, ihtiyaçlarını karşılayarak yaşam düzeylerini yükseltebilmek ve bunu koruyabilmek hem de toplumun kalkınması için bilinçli ve sorumlu eğitilmiş tüketicilere ve bilinç, sorumluluk ve etik temelli yeni bir tüketim anlayışının oluşmasına gerek vardır. Bilinç kavramı insanın kendisini ve çevresini tanıma yeteneğidir. İnsan bilinç ile faaliyetleri ve davranışlarının farkında olur ve kendini eleştirebilir. Tüketim olgusu da bilinç ile birlikte ele alındığında kontrol edilebilir bir davranış haline gelir. Bilinçli bir tüketici, eğitilmiş olması nedeni ile ekonominin ve toplumun değişmesini sağlayacaktır. (Zureik \& Mowshowitz, 2005).

Bu noktada üzerinde durulması gereken konu "bilinç ve sosyal sorumluluk temelli bir tüketim yapısının nasıl olması ve "bilinçli tüketici" nin ne tür özellikler taşıması gerektiğidir. Tüketim kültürünün küreselleşmenin de etkisiyle tüm dünyaya yayıldığı günümüz toplum yapısı içerisinde sadece hakkını savunma ya da kaliteli ve güvenli mal satın alma faaliyetleriyle sınırlı kalmayıp, bahsedilen tüm toplumsal, çevresel ve etik faaliyetleri de içerisine alan yeni bir "bilinçli tüketici" tanımının yapılması ve bu tanımlamanın tüketiciler tarafından da benimsenmesi gerekmektedir. 
Bu çalışma kapsamında sosyal sorumlu, çevre bilinçli, etik, sade tüketim ve rasyonel tüketim olmak üzere beş boyuttan oluşan ve yukarıda bahsedilen problemlerin çözümü ve toplum refahı için bir rehber olması düşünülen çok kapsamlı bir bilinçli tüketim davranışının sınırları çizilmeye çalışılmış ve tüm bu boyutlar ilgili teorilerle desteklenmiştir.

\section{Bilinçli Tüketimin Boyutları}

\subsection{Düşünümsel Modernite ile Ortaya Çıkan Bilinç Kavramı ve Sosyal Sorumlu Tüketim}

Alman sosyolog Ulrich Beck risk toplumu teorisi sonrasında, risklerle baş etmenin en iyi yolunun bu tehlikeler, sebepleri ve yan etkileri konusunda bilinçlenmeyi gerekli gören "düşünümsel (bilinçli) modernleşme" teorisini ortaya koymuştur. Bu teorinin temel ögeleri bilinç, bilgi, eleştirme, sorgulama ve karar sürecine katılımdır. Beck içinde yaşadığımız çağı modernleşmenin başlangıç dönemi olarak tanımlamaktadır. Bu modernliği önceki dönemlerden ayıran en önemli özellik "bilinç" kavramıdır (Beck, 2005). Düşünümsel modernleşme sanayi toplumunda ortaya çıkan her türlü yeniliğin ve gelişmenin eleştirisidir. Çünkü sanayi toplumundaki her yenilenme toplumda ve doğada iz bırakmaktadır (Soydemir, 2011). Beck, bu teori ile toplumsal yaşama müdahalenin gerekliliğinden bahsetmektedir (Beck, 2005: 55).

Beck modernliği sanayi modernliği ve bilinçli modernlik olmak üzere ikiye ayırmaktadır. Bilinçli modernlik evresinde bilimsel ve teknolojik tüm gelişmelerin sorgulanmadan kabul edilmemesi ve kullanılmaması gerekliliğinden bahsedilmektedir. (Beck, 1999). Bu aşamada bireyler kendi ürettikleri risklerle yüzleşerek, onlara çözüm aramakta ve bu çözüm "bilinç" olarak karşımıza çıkmaktadır. Bilinç çerçevesinde bu teorinin temel yapısını da akılcı ve mantıklı seçimler yapmak oluşturmaktadır. Beck bu süreci "katmerli modernlik" yani "modernleşmenin modernleşmesi” olarak adlandırmakta ve önceki modernlik aşamasında yapılan hatalardan ders çıkarılarak bu bilinçli modernlik aşamasına geçileceğini savunmaktadır (Beck, 1999).

Risklerin beraberinde getirdiği belirsizlikler, bilgi ve bilinçsizlik gibi kavramların ortaya çıkmasına ve önem kazanmasına neden olmuştur. Beck, ortaya çıkan teknolojik ve bilimsel her yeniliği ve gelişmeyi sorgulamadan kabul etmemek ve eleştirebilmek için bilginin gerekli olduğunu savunmaktadır. Bilinçsizlik ve aşırı bilginin yanlış kullanımının toplumları geri dönüşü olmayan ve daha büyük felaketlere sürükleyeceğini söylemektedir. $\mathrm{Bu}$ düşünce ile modernliğin geleceğinde bilinçsizliği bir kusur olarak görmektedir. Risk toplumunda ortaya çıkan tüm çevresel ve toplumsal tehditler (nükleer atıkların depolanması, küresel tehlikeler vb.) insanların bilimi, teknolojiyi ve kurumları hiç eleştirmeden kabullenmesi ve onlara koşulsuz güvenmesinin bir sonucudur. Beck (1992) insanların bilinçsiz ve bilgisiz olmasının ve bunun farkına varmalarının, bilgi arayışına giden yolda önemli bir adım olduğunu düşünmektedir. Bilgi ve risk arasında karşılıklı bir etkileşim bulunmaktadır. Her ikisi de birbirinin hem nedeni hem de sonucudur. 
Düşünümsel modernlik bilinç ve bilgi halinin keşfidir. Modernleşmenin bilinçsizliğini ortaya koyarak, gereken bilginin ortaya çıkmasını sağlamaktadır. İçerisinde yaşadığımız çağda yapılan tercihler gözden geçirilmez, sorgulanmaz, sonuçları düşünülmez ise insanlığın büyük felaketlerle karşılaşması kaçınılmazdır.

Genel olarak değerlendirildiğinde risk toplumu ile oluşmuş tüm risklerin, tehlikelerin ve tehditlerin çözümü bilinçli, kendi üstünde düşünen ve düşünümsel modernleşmede yatmaktadır. Toplumların yaşamlarını etkileyen yan etkilere karşı farkındalığın oluşması ve bilinçlenme düşünümsel modernleşme ile gerçekleşecektir. Bunu gerçekleştirirken yaşamın tüm alanlarında ve tüm faaliyetlerde mantık, akıl, eleştirme, sorgulama, inceleme, gözden geçirme gibi kavramlar ön plana çıkmalı ve tüm davranışların temelini oluşturmalıdır (Soydemir, 2012).

Risklerin tüm dünyaya yayılması ve yoğunlaşmasına yetkili kurumların gerekli önlemleri alamayarak güvenliği sağlamada yetersiz kalmaları sebep olmaktadır. Böyle bir toplum yapısı, bireylerin kendi içlerine dönerek, kendi yaşam tarzlarını sorgulamalarına, yeniden değerlendirmelerine ve olumlu yönde bir dönüşüme yol açmaktadır. Tüketim faaliyetleri açısından düşünüldüğünde, bireylerin her tüketim davranışının toplumda, çevrede bir iz bıraktığı ve bırakacağı bilincinin yaygınlaşmaya başlamasıyla sosyal sorumlu, etik ve çevre bilinçli tüketim davranış modelleri bireylerin kendi kişisel tercihleri olarak ortaya çıkmaya başlamıştır.

Tüketimin küresel olarak hızla yayıldığı bir dünyada bireylerin kendi tercihleri doğrultusunda tüketim davranışlarını değiştirmeye başlaması, kaynakların yok olması, toprak, su ve hava kirliliği, küresel ısınma, türlerin yok edilmesi, yoksulluk gibi pek çok çevresel ve toplumsal sorunun çözümü için başlangıç noktası olacaktır. Ancak kitle iletişim araçlarının da etkisiyle ve "biz de bunları hak ediyoruz" düşüncesiyle meşrulaşmakta olan ve giderek popülerleşen tüketim kültürü ve arzusu tüm toplumların bilinçlenmesi yönünde gidilecek daha çok yol olduğunu ortaya koymaktadır. Bu nedenle bu yönde atılmış olumlu bir adım olarak bilinç, sorgulama, eleştirel bakış gibi kavramları ön plana çıkaran düşünümsel modernleşme teorisi tüketim kavramının sosyal açıdan değerlendirilmesini ve sosyal sorumlu tüketim davranışının temellerini oluşturmaktadır.

Tüketici olarak gerçekleştirilen her satın alma davranışı ve seçilen her ürünün topluma ve çevreye etkisinin olmaması düşünülemez. Günümüzde tüketiciler, sadece ihtiyaçlarını ya da isteklerini karşılamanın ötesinde herhangi bir ürün satın alırken, çocuk işçiler, çevre kirliliği, etik ticaret ilkeleri, doğal kaynakların sınırlılığı gibi pek çok konuyu da göz önünde bulundurmaktadırlar. Bahsedilen bu konular ve daha pek çok konu literatürde pek çok araştırmacı tarafindan tüketimin sosyal sorumlu yönü olarak kavramsallaştırılmaktadır.

İlgili çalışmalar incelendiğinde sosyal sorumlu tüketicilerin toplumun refahını bozan işletmelerin ürünlerini satın alınmama (Roberts, 1995), bir ürün ya da hizmet satın alırken firsatlar kadar problemlerin de farkında olma, tüketimle ilgili problemlerin çözümü için bir vatandaş olarak gücünün bilincinde olma, toplumdaki sosyal olaylara duyarlılık gösterme 
(Webster ve Frederich, 1975: 188), satın alma kararları içerisine toplumsal faktörleri de dahil etme (Follows ve Jobber, 2000), tüketime eleştirel bakma ve sorgulama (Fosse-Gomez \& Ozcarlar-Toulouse, 2008) gibi davranışlar gösterdikleri belirlenmiştir. Bu tüketiciler, bireysel yaşamaktan çok, toplumcu ve toplulukçu bir yaşamı tercih ederler ve sadece kendilerini düşünmeyen, sosyal idealleri de önemseyen bireylerdir (McCarty \& Shrum, 2001: 94; Shanka \& Gopalan, 2005: 102).

Düşünümsel modernite kuramı çerçevesinde düşünüldüğünde bu çalışma kapsamında sınırları çizilmeye çalışılan sosyal sorumlu tüketici davranışı da işletmelerin sosyal sorumluluk projelerine önem veren, çalışan hakları, çocuk işçi çalıştırılması, engelli bireylerin istihdam edilmesi, ayrımcılık, hayvanlar üzerinde yapılan testler, nesli tükenen hayvanlar gibi sosyal problemlere duyarlı, uygulamalarını beğenmediği işletmeleri gerektiğinde boykot eden, piyasayı yönlendirme gücünün farkında, sosyal adalet duygusu gelişmiş, bireysel değil toplumcu yaşayan bireyler olarak kendini göstermektedir.

\subsection{Derin Ekoloji Teorisi ve Çevre Bilinçli Tüketim}

Sanayi devriminden sonra insanoğlu doğa üzerindeki hakimiyetini artırarak, büyük çevresel yıkımlara neden olmuştur. Çevre sorunlarının artarak tüm dünya için bir tehdit oluşturmaya başlamasıyla ekolojik hareketler siyasallaşmaya başlamış, bu durum da insanların çevreye olan duyarlılıklarını artırmıştır (Özer, 2001: 62).

Derin Ekoloji akımı çevre felsefesindeki akımlardan birisidir. İlk kez Norveçli bilim insanı Arne Naess tarafından bu kavram kullanılmıştır. Naess 1973 yılında yayınladığı "The Shallow and The Deep, Long-Ronge Ecology Movements: A Summary" isimli çalışmasında derin ekoloji teorisinin temel ilkelerinden bahsetmektedir. Derin ekolojinin alt yapısını eşitlik, bütünsellik, çeşitlilik, ortak yaşam, kirliliğe ve kaynakların tükenmesine karşı mücadele gibi kavramlar oluşturmaktadır.

"Derin Ekoloji” kendisini “insan merkezli” çevreciliğin tam karşısında ve "doğa merkezli” bir düşünce tarzı olarak tanımlamaktadır (Tamkoç, 1994). Düşünce tarzlarında değil sadece davranışlarda değişiklik yapmayı öneren diğer çevreci hareketlerden farklı olarak, derin ekoloji insanların öncelikle dünya görüşlerinde, değerlerinde, doğayı algılama biçimlerinde ve yaşam tarzlarında köklü değişiklikler yapması gerektiğinin savunmaktadır (Naess, 1973).

Naess bu teori ile derin ekoloji ve sı̆̆ ekolojinin farklılıklarını ortaya koymaya çalışmıştır. Öncelikle derin ekolojinin temelinde doğa ve insan birlikte yer almaktadır. Bu teori, insanın doğaya hakim olma düşüncesini eleştirmektedir ve bu düşünceye şiddetle karş1 çıkmaktadır. Derin ekoloji, çevresel sorunları sadece insanlara zarar vermemesi için çözümlenmesi şeklinde görmemekte, bu sorunu dünyada yaşayan tüm türler bağlamında düşünmektedir. Naess, devletlerin bir yandan yeryüzünün her yerinde egemenlik kurmaya, doğal yapıyı bozmaya çalışırken, diğer yandan da çevreyi sürdürülebilir kalkınma gibi politikalarla göstermelik olarak korumaya çalışmasını sığ ekoloji ve gölge ekoloji olarak 
nitelendirmektedir (Naess, 1986). Derin ekoloji çevre sorunlarının çözümü için kökten değişimi savunmaktadır.

Naess, doğa konusundaki bu yaklaşımını bütünlükçü bir yapı olan ekosofi olarak kavramsallaştırmaktadır (Naess, 1994: 13). Ekosofi doğayla ilgili holistik düşünme biçimi olarak tanımlanabilir. Naess'e göre ekoloji bilimi tek başına doğayla ilgili sorunların çözümünde yeterli olamamaktadır. Naess, ekoloji biliminin ekosu ile etik kuralların uygulanmasını içeren bilgelik kavramının Yunancadaki karşılığını birleştirerek ekosofi kavramını oluşturmuştur (Bodian, 1997: 37). Ekosofi, bilimden bilgeliğe geçişin gerekliliğine işaret eden bir kavramdır. Başka bir ifadeyle, Derin ekolojinin maneviyatçı bir eğilimi bulunmaktadır. Porritt'e göre derin ekolojinin temel amacı anlamını yitirmiş dünyaya yeniden anlam kazandırmaktır (Porritt, 1984: 64-67).

Derin ekoloji kavramının temellendiği düşünce akımlarından olan mistisizm, bütün var olan türlerin kutsal olduğunu, insanın diğer varlıkların efendisi olarak görülemeyeceğini, mutluluğun metalarda ya da maddi tüketimde değil, içsel zenginlikte olduğunu, bu nedenle de insanların sade bir yaşam sürmeleri gerektiğini söylemektedir. Derin ekolojinin ortaya koyduğu ekosofi kavramı da mistisizm düşünce biçimi ile yukarıda bahsedilen noktalarda büyük paralellikler taşımaktadır (Yardımcı, 2006: 40).

Naess diğer bir derin ekolojist olan George Session ile birlikte Derin Ekolojinin temel ilkelerini belirlemiştir. Bu ilkeler;

1. Yeryüzünde yaşayan insanlar ve insan dışında kalan tüm canlıların kendince bir değeri vardır. Bu nedenle de insan merkezci düşünceden vazgeçilmelidir.

2. Ekosistem bir bütün olarak içinde barındırdığ 1 çeşitlilikle değerlidir.

3. İnsanların yaşamsal ihtiyaçlarını karşılamak dışında, bu zenginlikleri ve çeşitliliği yok etmeye hakları yoktur.

4. Ekosistemdeki tüm yaşam dengeli olmalıdır.

5. Dünya nüfusunun giderek artması ekosistemi ciddi bir şekilde tehdit etmektedir. Ekosistemin devamlılı̆̆ı nüfustaki azalmayı gerekli kılmaktadır.

6. Temel ekonomik, teknolojik ve ideolojik yapıları etkileyecek olan politikaların mutlaka değiştirilmesi gerekmektedir.

7. Yüksek yaşam standardına sahip olmak yerine, yaşam kalitesinin artması temel ilke olmalıdir.

8. İnsanların üstüne düşen sorumluluğu yerine getirmesi ile büyük bir değişimin yaşanması kaçınılmazdır (Session \& Naess, 1984).

Bu ilkeler, tüketim toplumunda artan çevre sorunları ile birlikte doğal kaynakların ve çevrenin korunması için tüm tüketicilerin sahip olması beklenen ilkelerdir.

Çevre bilinciyle hareket eden tüketicilerin tüketim ve satın alma kararları çevreye karşı bir sorumluluk taşımaktadır. Ayrıca, bu tüketiciler kaynak kullanımında hem gelecek 
nesiller için hem de tüm insanlık için bir sorumluluk üstlenmektedirler (Nickell vd., 1976: 356). Derin ekoloji teorisi kapsamında da bireylerin çevreye karşı taşımaları gereken sorumluluktan bahsedilmektedir. Literatürde çevre bilinçli tüketiciler, bir ürün satın alırken, üretim koşulları, ürün içeriği, ambalajı, kullanımı ve atıldıktan sonra çevre üzerindeki etkileri konusunda bilgi edinerek, buna göre karar veren tüketiciler olarak tanımlanmaktadır. (Karaca, 2013: 100). Bu davranışlarıyla tüketiciler işletmelerin de faaliyetlerini gözden geçirmeleri yönünde bir baskı oluşturmakta ve üretim faaliyetlerini ve geliştirdikleri ürün çeşitlerini şekillendirebilmektedir.

Bu çalışma kapsamında derin ekoloji teorisi ile profili belirlenen ve bilinçli tüketim kavramının bir boyutu olarak sözü edilen çevre bilinçli tüketici ise, kendisini doğanın hakimi olarak görmek yerine, doğanın bir parçası olduğunu kabul eden, yeryüzündeki diğer türlerin ve ekosistemlerin yaşam hakkına saygı duyan ve onları korumak için çaba gösteren, tüm faaliyetlerinin doğa üzerindeki etkilerinin bilincinde olarak kirliliğin ve tahribatın durdurulması için elinden geleni yapan, doğanın çeşitliliğinin insan kullanımı için değil de kendisi için değer taşıdığını bilen, doğaya ve diğer türlere karşı ayrımcı olmayan, doğal kaynakların sınırlılığın farkında olarak kaynak israfını önlemeye çalışan, tüketim kültürüne karşı olan, sade bir yaşam tarzını benimseyen bilinçli bireylerdir.

\subsection{Gönüllü Sadelik Akımı ve Sade Tüketim}

Gönüllü sadelik tüketim kültürüne karşı bir akımdır. Bu akım, sanayi toplumu öncesi ortaya çıkmış fakat küreselleşmenin ve tüketim kültürünün etkisiyle uygulanamamıştır. İlk olarak, 1936 yılında Richard Gregg tarafından kavramsallaştırılmıştır. Bu akımın temel amacı, bireylerin tüketim bağımlılı̆̆ına bir son vermek, tüketim miktarını azaltmak ve bireyin kendi hayatının kontrolünü almasını sağlamaktır (Gregg, 1936). Bu akımın özünde bireyin dış dünyasında sade ve basit, iç dünyasında ise zengin bir yaşam sürmesi düşüncesi bulunmaktadır. (Elgin, 1993). Iwata'ya göre ise bu akımın temelinde yer alan en önemli ögeler bireyin kendi kendine yetmesi ve metalara daha az bağlı olmasıdır (Iwata, 1997: 223).

Gönüllü sadelik akımının öncülüğünü, sosyolog Duane Elgin yapmıştır. 1981 yılında Voluntary Simplicity (Gönüllü Sadelik) ismiyle bir kitap yayınlayan Elgin, basit yaşamaya dair uygulamaları sistemli bir şekilde ortaya koymaktadır. Bu kitap tüketim girdabında boğularak bir çıkış yolu arayan insanlara gönüllü olarak sade bir yaşamın nasıl sürdürülebileceği konusunda ipuçları vermektedir (Elgin, 1992).

Shama’ya (1985) göre Gönüllü Sadelik akımının altı temel boyutu bulunmaktadır. Bu boyutlar aşağıdaki gibi sıralanabilir:

- Madde Sadelik: Bireyin tüketim miktarını azaltarak yaşamını sadeleştirmesi,

- Belirleyicilik: Bireyin yaşamının kontrolünü alması,

- Çevresel Duyarlılık: Doğaya saygı ve insanın doğaya bağlılığının anlaşılması,

- İnsancıl Ölçek: Daha küçük ölçekli teknoloji bağımlılığı,

- Kişisel Gelişim: Bireyin iç dünyasını zenginleştirmesi ve kendini keşfetmesi, 
- Uygun Teknoloji: Ürünlerin kullanışlılığını artıracak ve enerji tüketimini azaltacak teknolojiler.

$\mathrm{Bu}$ altı boyutta görüldüğü gibi gönüllü sadelik teknolojiyi reddetme, yoksulluğu benimseme gibi düşüncelerden oluşmamaktadır. Bu akım sadece daha az tüketimi ve çevreye uyumlu, dost teknolojileri savunmaktadır. Gerçekte basit yaşam, tüketimi nasıl gerçekleştireceğini iyi bilmek ve bu sade yaşam tarzı ile mutluluğu keşfetmektir (Alexander, 2011: 113).

Giderek artan gösteriş amaçlı tüketim faaliyetleri, tüketimde adaletsizliğe, sınıflar arası eşitsizliğe, meta fetişizmine, insan sağlığına ve çevreye yönelik tehditlere sebep olmaktadır. Dolayısıyla toplum ve bireyler bu tehditlere karşı bilinçlendirilmelidir. $\mathrm{Bu}$ nedenle gönüllü sadelik akımı ile temellendirilen sade tüketim kavramı bilinçli tüketim davranışının bir boyutudur. Sade tüketim lüks ve gösteriş amaçlı tüketimden uzak durarak, sadece ihtiyaç temelli tüketim davranışını içermektedir.

\subsection{Erdem Etiği Teorisi ve Etik Tüketim}

Erdem etiği teorisi, pek çok etik teorisi gibi Aristo'nun etik teorisini temel alarak oluşturulmuş bir teoridir. Erdem kavramı felsefe tarihinin başlangıcından beri içinde yer almakta olan ve kurallar ile değerler arasındaki boşluğu dolduran bir kavramdır. Bireyin yapması gerekenleri en iyi biçimde yapması olarak tanımlanmıştır. Erdemli bir bireyden yaptığı her şeyi tam anlamılla ve mükemmel bir şekilde yapması beklenir (Gerritsma, 2014: $13)$.

Erdem etiği teorisi, bireylerin davranışlarını yargılarken eylem merkezli değil de eyleyen merkezli bir bakış açışına sahiptir. Yapılandan ziyade olunan ile ilgilenir. Temel sorusu "neler yapmalıyım ya da yapmamalıyım?" yerine "nasıl bir birey olmalıyım?" dır. Temel ögeleri, ödev, yükümlülük, sorumluluk değil, iyilik, mükemmellik ve erdemdir (Hursthouse, 1999: 25). Tüm bu özelliklere bakılarak, erdem etiğinin bireye odaklanan ve eylemi ikinci planda bırakan bir teori olduğu söylenebilir.

Erdem etiği bireyin taşıdığı kişisel özelliklerin önemini vurgulayarak, bireyin temel kişisel özellikleri olmadan konulacak ilke ve kuralların boş olduğunu belirtmektedir. Diğer bir ifadeyle, belli erdemlere sahip olmayan bireylerin kurallara uymasını beklemek boşuna olacaktır. Bu nedenle bu teori bireyin ikileme düştüğü bir durumla karşılaştığında "erdemli bir birey olsa ne yapardı?" sorusunu kendisine sorması gerektiğini söylemektedir. Erdem etiği teorisi "yapılması gerekeni" söylememekte, "olunması gereken" üzerinde durmaktadır (Kart, 2006).

Bütün tüketim faaliyetlerinin etik bir yanı ve bireylerin etik değerlerine dayalı bir yönü vardır (Chatzidakis vd, 2004). Erdem etiği teorisinin tüketim ile olan ilgisi, bireysel davranışlar ile tüketim arasında kurulan ilişki üzerinedir. 
Erdem etiği teorisi, etik tüketimi açıklamaya yönelik "nasıl davranmalıyım” sorusunu "nasıl bir birey olmaya çabalamalıyım?" şeklinde yeniden şekillendirmiş ve etik tüketime yeni bir bakış açısı getirmiştir. Bireyin diğerlerine olan sorumluluklarına değil, bireysel mükemmelliğe, toplumsal gelişmeye odaklanmaktadır. "İyi yaşam nedir, nasıl başarılabilir" sorusunu sorarak bireyleri kendi kişisel gelişimlerinin topluma da yansıyacağı konusunda aydınlatmaya çalışmaktadır. Bireysel gelişimi sağlayan değerler ve erdemler üzerinde özellikle durmaktadır (Hursthouse, 1999).

Erdem etiği teorisi, erdemlerin öğrenildiği ve edinildiği alışkanlık ve uygulamalara dikkat çekmektedir. Örneğin, hangi alışkanlıkların ve uygulamaların bizleri sürdürülebilir tüketim davranışına yönlendirdiği konusu ile ilgilenmektedir. Erdem etiği teorisi, etik tüketimin incelenmesi ve tanımlanması için uygun bir teoridir, çünkü etik tüketiciler "bireysel olgunluk, bütünlük ve sağlamlık" düşüncesi ile güdülenmektedirler (Barnett vd. 2005: 18). Diğer bir ifadeyle, her zaman tüketici olarak tercihlerinin sonuçlarını öngöremeseler de bunu umursamaktadırlar ve tüketim davranışlarında kişisel çıkarları ile fedakârlık ve özgecilik davranışını birleştirmektedirler (Shaw \& Newholm, 2003).

Erdem etiği teorisi "tüketim erdemli bir aktivite midir yoksa değil midir" sorusunu sorarak, tüketimin problemli taraflarını açıklamaya çalışmaktadır. Aristo, bireylerin sahip oldukları mallarla mutluluk ve zevk arasında bir bağlantı kurarak köleleştiklerinden bahsetmektedir (Barnett vd. 2005). Bu düşünceye göre, tüketim isteklerin tatminine dayalı hazcı bir eylemdir. Bu yönüyle tüketim, bireylerin kendilerini gerçekleştirdikleri ve zenginleştirdikleri aktif bir eylem olmaktan uzaklaşarak, pasif bir eylem haline gelmektedir. Tüketime dayalı bir yaşamda insanları hem sosyal hem kültürel hem de ahlaki olarak yozlaştırmakta ve pasifleştirmektedir. Erdem etiğinin üzerinde önemle durduğu konulardan birisi de bu noktadır (Barnett vd. 2005: 19).

Erdem etiği teorisine katkıda bulunan teorisyenlerden birisi de Alasdair MacIntyre'dır. MacIntyre'e göre, bir toplum içerisinde yaşamak bireylere alınması gereken bazı sorumluluklar getirir ve birey bu sorumluluklar sayesinde erdemlerini geliştirir ve kendisine ulaşabileceği hedefler koyar. Bu şekilde davranarak birey “iyi yaşam” olgusuna ulaşabilir (MacIntyre, 2007). Diğer bir ifadeyle, erdemler ancak yaparak, uygulayarak ve gerçekleştirerek oluşur.

MacIntyre, teorisinde amaç anlamına gelen Yunanca "telos" kavramından bahseder. Eylemlerin bir amacı olmalı ya da bir amaca ulaşmalıdır. Etik tüketim davranışının temel öğelerinden birisi de bir amaç barındırmasıdır. Etik tüketimi seçen tüketiciler tüketim davranışlarıyla, daha iyi bir dünyaya katkıda bulunmayı amaçlamaktadırlar. Bu amaç ile birlikte yaptıkları bilinçli tercihlerle dünyanın daha iyi bir yer haline gelmesi için belli bir politik duruş sergilerler. Örneğin, etik ticaret ilkelerine uyan bir işletmenin ürünlerinin tercih edilmesi, iş dünyanın daha temiz, daha ahlaklı ve daha adil bir hale gelmesi için yapılmış bilinçli bir seçimdir. Bu tarz davranışları sergileyenlerin ortak bir "telos" ları vardır.

MacIntyre'ın erdem etiğinden bahsederken vurguladığı bir diğer önemli kavram da kurallardır. Etik tüketim davranışında da kurallar önemlidir. Buna dayanarak, satın alınan 
bir ürünün sahip olması gereken sertifika ve belgelere dikkat edilmesi, satın alınması gereken yerlerden alınması, orijinal olarak üretilen ürünlerin tercih edilmesi, ödenmesi gereken ücretin eksiksiz ödenmesi ve satın alma işleminin yasalara uygun olarak gerçekleştirilmesi bu çalışmada geliştirilecek olan ölçeğin içerisinde yer alan önemli etik tüketim maddeleridir. Bu kurallar, aynı zamanda MacIntyre'ın odak noktasına aldığı kavramlardan "otoriteye saygı" ile de ilişkilidir. Ticari otoritelerin koyduğu kurallara uyan ve bunlara uygun ürün üreten işletmelerin tercih edilmesi etik tüketim davranışının bir parçasıdır ve bilinç göstergesidir. Bilinçli tüketiciler, etik ticaret etiketi taşıyan firmaların ürünleri için daha fazla ödeme yapmayı göze alan tüketicilerdir (Gerritsma, 2014: 40).

MacIntyre'a teorisinde içsel iyilik kavramından (internal goods) bahsetmekte ve içsel iyiliğe sahip olan bireylerin dünyayı daha iyi bir hale getirmek için çaba göstermeye hevesli olduklarını belirtmektedir. Erdemler de içsel zenginliğin geliştirilmesi için gerekli olan unsurlardır. Erdem sahibi tüketiciler de, tüketici olarak dünyayı daha yaşanabilir bir hale getirme konusunda üzerlerine düşen sorumlulukları yerine getiren ve etik davranan tüketicilerdir (MacIntyre, 2007).

Etik tüketim davranışını gerçekleştirmek için gerekli olan erdemler, bireyleri sosyal adalet, çevreye saygı, toplumsal ve bireyse sağlığın korunması gibi amaçlar 1şığında ürün seçmeye ve tüketmeye yöneltmektedir. Etik tüketim davranışı geliştirmeye çalışan bireyler, sosyal adaletin korunmasına katkıda bulunmak için etik ticaret ilkelerine saygı gösterirler. $\mathrm{Bu}$ ilkelere uyan işletmelerin ürünleri için daha fazla ödeme yapmaya isteklidirler. Burada önemli olan kavramlar "yansıtma" dır. Birey tüketim davranışının toplumda bir yansıması olduğu bilinciyle bu şekilde davranmaktadır. Diğer bir ifadeyle, etik ticaret ilkelerine uyan bir işletmenin ürünlerinin tercih edilmesi, topluma temiz ticaret ve sosyal adaletin sağlanması olarak geri dönmektedir. Bu davranışı gerçekleştirmek için bireyin sorumluluk, empati, bilgiyi arama gibi erdemlere sahip olmak gerekmektedir. Benzer şekilde çevre dostu ürünler satın alma davranışı çevresel kirliliğin azalması, çevrenin korunması, birey ve toplum sağlığına uygun ürünler tercih edilmesi, toplumun sağlık düzeyinin artması olarak geri dönecektir.

Erdem etiği teorisi kapsamında erdemli bir birey tüketici olarak davranışlarının ve yaptığı seçimlerin diğer bireyleri yani toplumu ve toplumsal ilişkileri etkileyeceğinin farkındadır. Birey bir ürünü almayı ya da almamayı seçerken, "doğru” ve "adil” olanı yapar, bu davranışı iyi bir birey olma ve iyi bir yaşam sürme hedefine katkıda bulunur (Gerritsma, 2014: 36). Erdem etiği teorisinden yola çıkılarak, yaptığı seçimlerin topluma yansımalarının farkında olan, ahlaki olgunluğa erişmiş ve "doğruluk", "dürüstlük" "fedakârlık" gibi erdemlere sahip bir tüketici düşüncesi bilinçli tüketici kavramının önemli bir boyutunu oluşturmaktadır.

Etik tüketim davranışı literatürde farklı araştırmacılar tarafından farklı içeriklerle çalışılmıştır. Tüketiciler etik bir tercihte bulunurken, üç faktörü göz önünde bulundururlar. Kusurun/kabahatin işlendiği yer, davranışın yasalara uygun olup olmaması ve sebep olunan zararın derecesi (Vitell vd. 1991). Örneğin satıcıya zarar vermeyen bir davranış etik olarak değerlendirilirken, yasal olmayan davranışlar etik dışı sayılmaktadır (Chan vd. 1998). 
Tallontire ve diğerleri. (2001), etik tüketim davranışının beş boyutu olduğundan bahsetmektedirler. Bunlar, sağlıklı besin, (organik gida da bu boyutta yer almaktadır), toplumsal gelişim (yerli satıcıların desteklenmesi), etik ticaret, hayvan koruma ve çevresel sürdürülebilirliktir. Tallontire ve diğerleri, (2001), bunun dışında etik tüketimi amacına yönelik olarak üç boyutta değerlendirmektedir. Etik olarak üretilen bir ürünün tercih edilmesi etik tüketimin pozitif yönüdür. Tüketicinin uygulamalarını beğenmediği işletmelerin ürünlerini tercih etmeme davranışı yani boykot etik tüketimin negatif boyutu olarak düşünülebilir (Smith, 1990). Diğer boyut ise etik tüketimin "tüketici hareketi" kapsamında değerlendirilerek, satın almanın ötesinde, satıcı ve sağlayıcılarla ilişkiler, hükümet kararlarının etkilenmesi için yürütülen lobi faaliyetleri gibi bu kapsamda yer almaktadır. Bu boyuta göre, etik tüketici öncelikle vatandaştır (Tallontire vd. 2001: 6).

Etik tüketim davranışının en önemli boyutu, sadece bireylerin tüketim alışkanlıklarının değiştirilmesi değil, modern tüketimin anlamının, hedeflerinin ve tüketiciye yüklediği sorumlulukların tüm bireyler tarafından anlaşılmasıdır (Barnett vd. 2005). Langeland (1998), bireylerin etik tüketim davranışları gerçekleştirerek kişiliklerini geliştirdiklerini ve kimliklerini bulduklarını belirtmektedir. Tüketicilerin, etik olduğunu düşündükleri ürünleri tercih edip, etik olmayandan uzak durmaları işletmelere neyin üretilip neyin üretilmeyeceği ve üretim sürecinin nasıl olacağı konusunda mesaj vermektedir (Allison, 2009). Bireyler etik olarak üretilmiş ürünleri tercih ederek, ahlaki konular, çevresel ve toplumsal problemlere ilişkin endişelerini göstermektedirler (Carrigan \& Attala, 2001).

Bu çalışma kapsamında sözü edilen etik tüketici davranışı sahip olduğu doğruluk, dürüstlük gibi erdemleri tüketim davranışına da yansıtan, etik ilkeler çerçevesinde tüketim davranışında bulunan, yasal olmayan ürünleri ve hizmetleri tercih etmeyen ve bunlara tepki gösteren, kendi hakları kadar satıcı ve üreticinin haklarını da önemseyen, ahlaki olarak belli bir olgunluk seviyesine ulaşmış tüketicidir.

\subsection{Planlı Davranış Teorisi ve Rasyonel Tüketim}

Planlı Davranış Teorisi, Ajzen tarafından geliştirilmiş, tutum ile davranış arasındaki ilişkileri inceleyen araştırmalar sürecinin sonunda ortaya çıkan teorilerden biridir. Ajzen ve Fishbein'e (1975) göre, bireyler belirli bir davranışı gerçekleştirmeden önce eylemlerinin içeriklerini analiz ederler, genellikle rasyonel davranırlar ve bilgiyi sistematik şekilde mantık süzgecinden geçirerek kullanmaktadırlar. Planlı Davranış teorisinin temelini oluşturan ve bu çalışmanın "rasyonel tüketim" davranışı için de teorik altyapıyı oluşturan düşünce ise, "bireylerin herhangi karar verirken, mantık odaklı düşündükleri, bilgiye ulaşarak ve onu kullanarak rasyonel kararlar verdikleri ve planlı davrandıkları” düşüncesidir. Bireylerin davranışları, davranışları etkileyen faktörlerin bilişsel bir süreçten geçirildiği mantıksal bir sürecin sonucudur (Ajzen \& Fishbein, 1975). Gerçek eylemleri, tutumlarından, tavırlarından, öznel normlarından, davranışsal niyetlerinden, algılanan davranış kontrolünden etkilenmektedir. Davranışsal niyetleri ise, davranışa yönelik kişisel tutum, subjektif normlar ve algılanan davranışsal kontrolden etkilenmektedir (Ajzen \& Fishbein, 1975). 
Burada tutum, bireyin davranışa yönelimini, subjektif normlar, davranışı etkileyen sosyal baskı ve yakınların etkisini ifade etmektedir. Bireyin referans aldığı kişilerin, herhangi bir davranışa karşı tutumu (subjektif norm) olumlu ise bu tutum bireyi o davranışı gerçekleştirmeye itecektir. Algılanan davranışsal kontrol ise, bireyin kendi eylemleri üzerindeki kontrol düzeyini algılama biçimleri anlamına gelmektedir. Birey davranışı üzerinde kontrol sahibi olduğunu algılıyor ise o davranışı gerçekleştirme olasılığ yüksektir (Nunko \& Ramkissoon, 2010).

Davranışa yönelik tutum bireylerin o davranışla ilgili olumlu ve olumsuz değerlendirmelerini ifade etmektedir. Belli bir davranışa yönelik olumlu tutuma sahip olmayan bireylerden o davranışı gerçekleştirmesi beklenemez. Örneğin, bir tüketicinin bir ürünü satın alma faaliyetini gerçekleştirmesi için, o ürünün ya da markanın kendisine fayda sağlayacağına ilişkin bir tutum geliştirmiş olması gerekmektedir. Aksi takdirde satın alma işlemi gerçekleşmeyecektir. Bu tutum üründen tam performans almaya, ürünün bireye prestij katmasına, işlerini kolaylaştırmasına ya da zenginliğini göstermesine yönelik olabilir.

Subjektif norm ise, bireyin kendisine referans olarak aldığ 1 kişilerin davranışla ilgili düşünceleridir. Toplum baskısı ya da sosyal baskı olarak da ifade edilebilir (Ajzein \& Fishbein, 1975). Bireyin herhangi bir davranışı gerçekleştirmesinde sübjektif normlar, bireyi yönlendirmektedir. Örneğin, çok pahalı ve lüks bir ürünü satın alırken, birey içerisinde bulunduğu sınıfın davranışlarından etkilenerek, onların onaylayıp onaylamamalarına göre satın alma davranışını gerçekleştirecektir.

Algılanan davranışsal kontrol ise, davranışı sergileyebilmenin zorluğuna ya da kolaylığına ilişkin inancı ifade etmektedir. Bireyin gerçekleştirmek istediği davranış, bir fayda içeriyorsa ve kişisel normlar ile de örtüşüyorsa bieyin o davranışı gerçekleştirmesi muhtemeldir. Bireyin, davranışı gerçekleştirmek için kullanılacak kaynaklara ulaşabilmesi ve kaynakların fazlalığı ile engellerin azlığı o davranış üzerindeki bireyin algılanan kontrolünün yüksek olduğunu göstermektedir (Ajzen, 1991). Bireyin algılanan davranışsal kontrolünün yüksek olduğu davranışların gerçekleşme olasılığı da yüksektir.

$\mathrm{Bu}$ teoriye göre niyet davranışın en önemli belirleyicisidir. Olumlu yönde bir niyet davranışın gerçekleşmesi olasılığını güçlendirir. Bir eylem için gereken kaynak ve olanaklar yeterli değilse, o davranışa niyet edilmesi olasılığı düşüktür (Ajzen, 1991). Bu noktada davranışa yönelik niyet ile amaca yönelik niyet arasındaki farkın da ortaya konulması gerekmektedir. Örneğin, “doğa dostu ürünleri satın alma niyeti” davranışsal bir niyeti ortaya koyarken, “doğal kaynakların korunmasını sağlamak" amaca yönelik bir niyeti göstermektedir. Burada önemli olan nokta, bireylerin doğal kaynakların korunmasına yardımcı olmak amacıyla çok çeşitli alternatif davranışsal niyetlere sahip olabilmeleri olasılığıdır. Başka bir ifadeyle, doğa dostu ürünleri satın almak özellikli bir davranışsal niyeti göstermektedir. Bu örnekten de anlaşlacağı üzere, bu teoriye göre bireyin tüm davranışları bir sebebe bağlı olarak ortaya çıkmaktadır. Davranışlar gelişi güzel gerçekleştirilmez, davranışa yönelik kararlar bilişsel bir süreçten geçirilerek ve bir niyete dayandırılarak rasyonel bir şekilde verilir. 
Bu teori eyleme geçilmeden önce eylem üzerinde mantıklı bir şekilde düşünülerek, eylemin bilinçli olarak gerçekleştirildiğini öne sürmektedir. Bilinçli tüketim davranışının rasyonel tüketim boyutunda profili çizilmeye çalışılan tüketici de elindeki kaynakları ve sahip olduklarını göz önünde bulundurarak, yakınlarının ve sosyal çevrenin de görüşlerini alarak, alternatifleri bir mantık sürecinden geçiren buna göre karar veren ve plan yapan bilinçli bir tüketicidir. Bu teori rasyonel bireyin davranışı, davranışsal niyeti ve bilgilendirilme sürecinin anlaşılması için uygun bir altyapı oluşturmaktadır.

\section{Sonuç}

Tüm bu kuram ve akımlardan yola çıkarak, bu çalışma kapsamında beş boyut ile tanımlanmaya çalışılan bilinçli tüketici kavramı bahsedilen tüm sorunları odak noktasına alarak, bir ürün ya da hizmeti satın alırken temel ihtiyaçlarına öncelik veren, satın alacağ 1 mal ve hizmetlerin kaliteli, güvenli, standardı yüksek, sağlıklı ve çevre dostu olmasına dikkat eden, alışverişin nesnesi değil öznesi olduğunun bilincinde olan, tüketici olarak haklarını bilen, haklarına sahip çıkan ve savunan, medyanın ve reklâmların etkisinde kalarak yanlış tercihler yapmayan, israftan ve lüks tüketimden kaçınan, etik davranan, tüketim davranışının topluma ve çevreye olan etkilerinin farkında olan ve içinde bulunduğu toplumun gelişmesi için her türlü değişimi destekleyen açık fikirli bir birey olarak tanımlanabilir.

Bu tanımlamanın oluşturulabilmesi ve bilinçli tüketicinin profilinin çizilebilmesi için bilinç, sorgulama, eleştirel bakış gibi kavramların gerekliliğini ortaya koyan ve bunlara olan ihtiyacı ön plana çıkaran düşünümsel modernleşme teorisi sosyal sorumlu tüketim davranışının, insanın doğanın hakimi değil bir parçası olduğunu savunan, yeryüzündeki diğer türlerin ve ekosistemlerin yaşam hakkına saygı duyan ve onları korumak için çaba gösterilmesi gerekliliğini vurgulayan ve tüketim kültürüne karşı olan derin ekoloji teorisi çevre bilinçli tüketim davranışının, sade bir yaşam tarzına dikkat çeken, maddi değil manevi zenginliğin artırılması gerekliliğine odaklanan, çevresel duyarlılık ve tasarruf bilincini vurgulayan gönüllü sadelik akımı sade tüketim davranışının, belli erdemlere sahip olmayan bireylerin kurallara uymasını beklemenin boşuna olacağını vurgulayan erdem etiği teorisi etik tüketim davranışının, bireylerin belirli bir davranışı gerçekleştirmeden önce eylemlerinin içeriklerini analiz ettiğini, genellikle rasyonel davrandıklarını öne süren planlı davranış teorisi ise rasyonel tüketim davranışının sınırlarının belirlenmesinde yararlanılacak kuramsal altyapıyı oluşturmaktadır.

Günümüzde sağlıklı ve yaşanabilir toplumların ve dünyanın oluşturulmasında işletmelere olduğu kadar sosyal sorumlu, etik, rasyonel ve çevre bilinciyle hareket eden tüketicilere de önemli görevler düşmektedir. Bilinç tüm bu davranışların kazanılmasında anahtar role sahiptir. Daha bilgili ve bilinçli tüketiciler, daha etik davranan daha temiz işletmeler ve piyasa sistemi için daha çok talepte bulunacaklardır. Bilinçli tüketim eğilimi arttıkça, işletmeler, karar alıcı ve kural koyucu mekanizmalar için de sosyal sorumlu, etik, çevre dostu ve rasyonel tüketim davranışlarının ve böyle davranan tüketicilerin önemi artmaktadir. 
Bilinçli tüketim davranışının önündeki en büyük engellerden birisi bilgi eksikliğidir. Bu bilgi eksikliğinin giderilmesinin ve bilinçli tüketim davranışı geliştirmenin ilk aşaması da tüketimle ilgili problemlerin ve yapılması gerekenlerin farkına varılmasıdır. $\mathrm{Bu}$ çalışmanın gerçekleştirilme amaçlarından birisi de bilinçli tüketim davranışının neleri kapsadığını belirleyerek, yapılması gerekenleri ortaya koymaktır.

Aşırı tüketim davranışının giderek popülerleştiği, günümüz tüketim toplumunda satın alma ve tüketim davranışlarının gerek doğal çevreye, doğal kaynaklara ve toplumda yaşayan diğer bireylere ve dolayısıyla toplum geleceğine ve refahına olan etkisi ortadadır. Bu nedenle tüketicilerin, bilinçli tüketim davranışına olan ilgi ve yaklaşımları ortaya konulmalı ve incelenmelidir. Bu bağlamda, bahsedilen çok boyutlu tüketim bilincine sahip bireylerin sayısının artırılması için, geniş kapsamlı bilgilendirme ve bilinçlendirme çalışmalarına ihtiyaç duyulmaktadır. Bilinçli tüketim davranışı geliştirilmesi, somut olarak davranışlarda gerçekleşecek küçük değişiklikler, soyut olarak tüketim ile ilgili düşünce yapısının değiştirilmesi ile mümkün olacaktır. Bu değişim için özellikle eğitim kurumlarına, üniversitelere, araştırma merkezlerine ve toplumun bu konuda bilinçlendirilmesi için ilgili kamu kurumlarına önemli görevler düşmektedir. Tüm kurumlar tüketicilerin bahsedilen bilinçli tüketim davranışının boyutları ve tüketim davranışının toplum geleceğine etkisi konusunda bilgilendirilmesi için ortak çalışmalar gerçekleştirmelidir. Dünyanın ve dünya üzerinde yaşayan tüm canlıların geleceği, tüm bireylerin tüketim davranışlarını sorgulayarak, bu davranışlarında akıl ve mantık odaklı ve bilinç çerçevesinde davranışlar sergilemelerine bağlıdır.

\section{Kaynaklar}

Ajzen, I. \& M. Fishbein (1975), Belief, Attitude, Intention and Behavior: An Introduction to Theory and Research, <http://people.umass.edu/aizen/f\&a1975.html>, 21.01.2015.

Ajzen, I. (1991), “The Theory of Planned Behaviour”, Organisational Behaviour and Human Decision Processes, 50(2), 179-211.

Alexander, S. (2011), "The Voluntary Simplicity Movement: Reimagining the Good Life Beyong Consumer Culture", International Journal of Environmental, Cultural, Economic, and Social Sustainability, 7(3), 133-150.

Allison, G.M. (2009), “Pursuing Status Through Ethical Consumption?”, in: D. Tojib (Ed.) Sustainable Management and Marketing, ANZMAC Conference, Monash University, Melbourne.

Barnett, C. \& P. Cafaro \& T. Newholm (2005), "Philosophy and Ethical Consumption", in: R. Harrison \& T. Newholm \& D. Shaw (Eds.), The Ethical Consumer, 11-24; London: Sage Publication.

Bauman, Z. (1999), Çalışma, Tüketicilik ve Yeni Yoksullar, (Çev. Ümit Öktem), İstanbul: Sarmal Yayınları.

Bauman, Z. (2006), Küreselleşme, 2. Basım, İstanbul: Ayrıntı Yayınları.

Beck, U. (1992), Risk Society: Towards a New Modernity, London: Sage Publications.

Beck, U. (1999), World Risk Society, Cambridge: Polity Press.

Beck, U. (2005), Power in the Global Age: A New Global Political Economy, Trans. Katherine Cross, Cambridge: Polity Press. 
Bodian, S. (1997), “Arne Naess ile Bir Söyleşi: Sade Yaşama Ulaşan Doyurucu Yollar veya Sade Fakat Doyurucu Yaşam”, A ğaçkakan Alternatif Ekolojist Seçki, (Çev. G. Tamkoç), 32.

Carrigan, M. \& A. Attala (2001), "The Myth of the Ethical Consumer Do Ethics Matter in Purchase Behavior?", Journal of Consumer Marketing, 18(7), 560-577.

Chan, A. \& S. Wong \& P. Leung (1998), "Ethical Beliefs of Chinese Consumers in Hong Kong", Journal of Business Ethics, 17, 1163-1170.

Chatzidakis, A. \& S. Hibbert \& D. Mittutis \& A. Smith (2004), "Virtue in Consumption?", Journal of Marketing Management, 20, 527-544.

Coşgun, M. (2012), "Popüler Kültür ve Tüketim Toplumu”, Batman University Journal of Life Sciences, 1(1), 837-849.

Ekin, V. (2010), “Tüketim Toplumu, Hedonizm ve Araç Olarak Yazılı Basın”, Marmara Üniversitesi, Sosyal Bilimler Enstitüsü, İletişim Bilimleri Anabilim Dalı, Genel Gazetecilik Bilim Dalı, Doktora Tezi, İstanbul.

Elgin, D. (1993), Voluntary Simplicity: Toward a Way of Life That Is Outwardly Simple, Inwardly Rich, New York.

Follows, S.B. \& D. Jobber (2000), "Environmentally Responsible Purchase Behavior: A Test of a Consumer", European Journal of Marketing, 34 (5/6), 723-746.

Fosse-Gomez, M.H. \& N. Ozcarlar-Toulouse (2008), “Towards an Understanding of Consumption Objectors", European Advances in Consumer Research, 8, 493-497.

Fromm, E. (2002), Yeni Bir İnsan Yeni Bir Toplum, (Çev. Necla Arat), İstanbul: Say Yayınları.

Gerritsma, H. (2014), "Ethical Consumption of Food What Virtues Are Needed for The Individual Consumer That Seeks for Ethical Consumption?", Utrecht University, Graduate School of Humanities, Master of Applied Ethics Thesis, Utrecht, Holland.

Giddens, A. (1998), Beyond Left and Right, Cambridge: Polity Press.

Gregg, R. (1936), "Voluntary Simplicity”, Visha-Bharati Quarterly, reprinted in Manas in 1974.

Hall, S.M. (2015), "Everyday Ethics of Consumption in the Austere City", Geography Compass, 9(3), 140-151.

Hursthouse, R. (1999), On Virtue Ethics, Oxford: Oxford University Press.

Iwata, O. (1997), “Attitudinal and Behavional Correlates Of Voluntary Simplicity Lifestyles", Social Behavior and Personality, 25(3), 223-240.

İnsel, A. (1997), “Geçmişten Geleceğe”, Birikim Dergisi, Şubat Sayısı, İstanbul: Birikim Yayınları.

Kahvecioğlu, Y. (2004), “Tüketim Toplumu, Çevresel Risk ve Türkiye”, Uludağ Üniversitesi, Sosyal Bilimler Enstitüsü, Yüksek Lisans Tezi, Bursa.

Karaca, Ş. (2013), “Tüketicilerin Yeşil Ürünlere İlişkin Tutumlarının İncelenmesine Yönelik Bir Araştırma", Ege Akademik Bakış, 13(1), 99-111.

Kart, B. (2006), “Erdem Etiği Normatif midir?”, FLSF Dergisi, 2, 101-108

Langeland, L. (1998), “On Communicating the Complexity of a Green Message”, Greener Management International, 25, 81-91.

MacIntyre, A. (2007), After Virtue: A Study in Moral Theraphy, Indiana: University of Notre Dame Press.

Marcuse, H. (1986), Tek Boyutlu İnsan, (Çev. A. Yardımlı), İstanbul: İdea Yay. 
McCarty, J.A. \& L.J. Shurm (2001), "The Influence of Individualism, Collectivism and Locus of Control on Environmental Beliefs and Behaviour", Journal of Public Policy \& Marketing, 20(1), 93-104.

Naess, A. (1973), "The Shallow and the Deep, Long-Range Ecology Movement: A Summary", Inquiry An Interdisciplinary Journal of Philosophy and the Social Sciences, 16, 95-100.

Naess, A. (1986), “The Deep Ecology Movement: Some Philosophical Aspects”, Philosophical Inquiry, 8, 10-31.

Naess, A. (1994), Derin Ekolojinin Temelleri, Derin Ekoloji, Derleyen: Günseli Tamkoç, İzmir: Ege Yayınları

Nickell, P. \& A.S. Rice \& S. Tucker (1976), Management in Family Living, New York: John Wiley and Sons Publication.

Nunko, R. \& H. Ramkissoon (2010), “Gendered Theory of Planned Behaviour and Residents' Support for Tourism”, Current Issues on Tourism, 13(6).

Odabaş1, Y. (1999), Tüketim Kültürü, İstanbul: Sistem Yayınları.

Odabaş1, Y. (2004), Postmodern Pazarlama Tüketim ve Tüketici, İstanbul: MediaCat.

Özer, M.A. (2001), “Ekolojik Harekette Yol Ayrımı: Yeşiller ve Derin Ekoloji”, Yerel Yönetim ve Denetim Dergisi, 6(9).

Porrit, J. (1994), "Yeşil Ruh Yaşayacak", Derin Ekoloji içinde, (Der. G. Tamkoç) İzmir: Ege Yayincilik.

Rey, P.J. \& G. Ritzer (2012), “The Sociology of Consumption”, in: G. Ritzer (eds.), The Wiley Blackwell Companion to Sociology, Blackwell Publishing, 444-468.

Roberts, J.A. (1995), "Profiling Levels of Socially Responsible Consumer Behavior: A Cluster Analytic Approach and Its Implications for Marketing", Journal of Marketing Theory and Practice, 3(4), 97-117.

Session, G. \& A. Naess (1984), The Basic Principles of Deep Ecology, <https://www.uwosh.edu/facstaff/barnhill/ES-/pp\%20outline\%20Deep\%20Ecology.pdf>, Ocak 2015.

Shama, A. (1985), “The Voluntary Simplicity Consumer”, The Journal of Consumer Marketing, 2, 57-63.

Shanka, T. \& G. Gopalan (2005), Socially Responsible Consumer Behavior-Higher Education Student's Perceptions, ANZMAC 2005 Conference: Corporate Responsibility, 102-107.

Shaw, D. \& T. Newholm (2003), "Consumption Simplicity among Ethical Consumers”, in: Serge P. Shohov (Ed.), Advances in Psychology, 20, 175-192.

Soydemir, S. (2011), "Modernizmin Karanlık Yüzü: Risk Toplumu”, Sosyal ve Beşeri Bilimler Dergisi, 3(2), 169-178.

Şan, M.K. \& İ. Hira (2007), "Frankfurt Okulu ve Kültür Endüstrisi Eleştirisi”, Sosyoloji yazıları I, (Sakarya Üniversitesi Sosyoloji Bölümü Ortak Çalışması) İstanbul: Kızılelma Yayınları, 324- 340.

Şentürk, Ü. (2008), “Modern Kontrol: Tüketim”, C.Ü. Sosyal Bilimler Dergisi, 32(2), 221-239.

Tallontire, A. \& E. Rentsendorj \& M. Blowfield (2001), Ethical Consumers and Ethical Trade: A Review of Current Literature. Policy Series 12. Chatham UK: National Resources Institute.

Tamkoç, G. (1994), “Derin Ekolojinin Genel Çizgileri”, Birikim Dergisi, 57-58: 87-91. 
Tolan, B. (1991), Toplum Bilimlerine Giriş, 3. Baskı, Ankara: Adım Yayınları.

Touraine, A. (2000), Modernliğin Eleştirisi, (Çev. H. Tufan), İstanbul: YKY Yayınları.

Ünay, S. (2010), "Neoliberal Küreselleşme ve Evrensel Tüketim Toplumunun Yükselişi”, Tüketim ve Değerler. Ed. Recep Şentürk, İstanbul Ticaret Odası, İstanbul, 73-83.

Velasques, M.G. (1998), Business Ethics: Concepts and Cases, New Jersey-ABD: Prentice Hall Inc.

Vitell, S.J. \& J.R. Lumpkin \& M.Y.A. Rawwas (1991), "Consumer Ethics: An Investigaton of Ethical Beliefs of Elderly Consumers", Journal of Business Ethics, 10, 365-375.

Weber, M. (1999), Protestan Ahlakı ve Kapitalizmin Ruhu (Çev. Z. Gürata), Ankara: Ayraç

Webster, Jr. \& E. Frederich (1975), "Determining the Characteristics of the Socially Conscious Consumer", The Journal of Consumer Research, 2(3), 188-196.

Yardımcı, S. (2006), “İnsan-Doğa İlişkisi Ekseninde Derin Ekoloji ve Toplumsal Ekoloji”, Ankara Üniversitesi, Sosyal Bilimler Enstitüsü, Siyaset Bilimi ve Kamu Yönetimi Anabilim Dalı, Yüksek Lisans Tezi, Ankara.

Zureik, E. \& A. Mowshowitz (2005), "Consumer Power in the Digital Economy”, Communications of the ACM, October, 48(10), 46-51. 